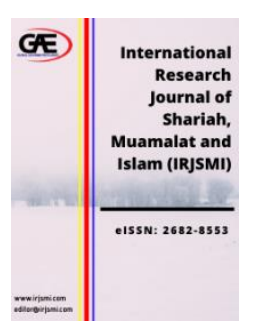

International Research Journal of Shariah, Muamalat and Islam (IRJSMI)

Journal Website: http://irjsmi.com/ eISSN: 2682-8553

\title{
STUDENTS' ETHICS AND RELIGION: A STUDY AT UNIVERSITY MALAYSIA SABAH, LABUAN INTERNATIONAL CAMPUS
}

\author{
Azizan $\mathrm{Had}^{1}$, Starry Garijih ${ }^{2}$ \\ 1 Center for the Promotion of Knowledge and Language Learning, Universiti Malaysia Sabah, Malaysia \\ Email: azizan@ums.edu.my \\ 2 Researcher, Labuan, Sabah, Malaysia \\ Email: starry_emerson@yahoo.com
}

\section{Article Info:}

\section{Article history:}

Received date:23.03.2020

Revised date: 14.05 .2020

Accepted date: 17.05.2020

Published date: 15.06 .2020

\section{To cite this document:}

Had, A., \& Garijih, S. (2020). Students' Ethnics and Religion: A Study at Universitiy Malaysia Sabah, Laabuan International Campus. International Research of Shariah, Muamalat and Islam, 2 (4), 85-103.

DOI: $10.35631 /$ IRJSMI.24008.

\begin{abstract}
:
The research tries to answer the question of 'does religion, education, and social surroundings play a role in developing a student's ethical behavior?' To understand more on the topic, I have surveyed students at the Labuan branch of University Malaysia Sabah in Malaysia, a public university where most of the students are taking a first degree in Business and Computer Studies. Using a survey questionnaire, I test five important hypotheses: whether ethical attitudes are affected by religiosity, religion, social life, university education, and by what happens around them at home. The objective of the survey is to determine whether their awareness of ethical conduct is based on their religion, courses taken at the university, or other external factors. The result of the survey will show whether ethical awareness is determined by internal factors such as religion and home education, or by external factors such as university and school education, courses taken at the university or their social life.
\end{abstract}

Keywords:

Ethics, Awareness, Students, Religion, Religiosity Labuan, Malaysia

\section{Introduction}

The word ethics comes from the Greek word 'ethos' that means character or customs. As a branch of philosophy under axiology ethics can be defined as 'a set of moral behavior that develops over the years' (MacKinnon 2001:3). MacKinnon further elaborates that 'although the values may initially come from one 's family upbringing, they later result in one's own choice'. If we are to accept the definition given by MacKinnon, we are to accept two other distinct elements in his definition of ethics, the first being 'age/maturity as the determinant of ethical awareness' and secondly 'the social context which also plays an important role where 
ethical and moral values are dispersed'. Recent researches in the ethical behavior of students show that there are indifferent findings to the question of what social context, age, religion, and culture plays in determining a person's ethical behavior and awareness.

If we look back in history, we could see that there are many cases of unethical behavior in the local and international stage which draws much public attention. Cases of unethical behavior among large corporations in the international stage have received considerable attention from the corporate, academic, and public sectors over the past. In the last decade, the alleged behavior at Enron and Arthur Andersen (including shredding of subpoenaed documents and falsification of financial documents) as well as other highly publicized scandals (e.g., WorldCom) have come under scrutiny and again brought the topic of business ethics to the public's attention. As these scandals make all too clear, unethical behavior is costly to firms, their employees, and their investors (Conroy and Emerson 2004: 383).

In Malaysia, cases of criminal breach of trust among employees and officials entrusted to do their work with honesty and trustworthiness had shown a major increase. Most of the cases involve clerks, officers, lawyers, and even politicians. One might question if the idea of misconduct started when a person is still at tender years while studying in a school or university. Most researchers are in disagreement with the findings of their research on the answer to this question. As a developing nation, Malaysia was also not spared from the adverse effects of globalization in which there are symptoms and social events that occurred as a result of the internet and peer influences that cause the symptoms such as this increasingly prevalent.

These symptomatic influences on teenagers are immense and between 2001 and 2010 there was a threefold increase in the cases of rape (statistics from the Malaysian Ministry of Women, Family and Community Development), the number of cases of abandoned babies recorded is 383. The number is increasing from year to year and most of those affected are youngsters/teenagers, including students from schools and universities. Therefore, we need to realize and investigate the cause of the social ills among students to understand the causes of such occurrences.

Over the last decade, studies have raised serious questions about the ethical value of students and their awareness of ethical issues. One such research, by Prior et. al (2002) surveys ethical attitudes of information systems personnel and found out that younger (under 25 years old) respondents are more willing to do their work even though it is unethical compared to older and experienced respondents. The research also finds that employees feel that it is more unethical to take physical objects (even a paper clip) as opposed to using free resources such as their computer for playing games or other activities.

The objective of the research is to explain for the first time ethical awareness of students in a government university in Malaysia in the state of Sabah. One may ask why Labuan? The settings on this small island are considered as most appropriate for the study of ethical behavior since it is isolated from the mainland of Sabah and the Peninsula (West Malaysia). Students at the campus also come from various backgrounds, where some of them come from other big cities such as Kuching and Kota Kinabalu while some come from Peninsula Malaysia from the city-state of Kuala Lumpur, Shah Alam and other areas in the Peninsula. There are a small number of international students studying at the campus coming from China. Furthermore, the variety of students from different social and economic ladder proves that the selection of the location as most suitable for such research. Moreover, some cases of ethical behavior in previous research only focus on students in West Malaysia. There is no such research made 
based on the cultural comparison between students from East and West Malaysia. The variety of students at the university within a confined area provided a good setting for the research.

\section{Specific Research Issue and Limitation}

The following specific research questions were investigated in the study:

(1) Do male and female students differ in their attitudes toward the ethical acceptability of behaviors in specific situations?

(2) Are attitudes toward the ethical acceptability influenced by the religion of the individual exhibiting the behavior?

(3) Do male and female students' attitudes toward the ethical acceptability of behavior depend on whether they understand and learn about ethics while in school?

(4) Do business majors differ in their attitudes toward what constitutes ethical behavior from other academic majors?

(5) Does the strength of spiritual/religious beliefs affect attitudes toward the acceptability of ethical behavior?

(6) Does university education provide enough information to guide students in attaining an ethical academic behavior?

(7) This paper does not claim to cover all ethical aspects and behavior. The writers acknowledge that the term ethics is a broad term that refers to a wide range of behavior that includes a wide range of professions. The paper only covers ethical behavior that is considered unacceptable to the Asian and Muslim community especially in Malaysia. For example, abortion is illegal in Malaysia but in other countries, the law is different. In this study, students have been informed that the question to be asked in the study only covers ethical issues such as abortion, dumping babies, euthanasia, academic and work ethics.

\section{Literature Review}

The literature review of the relationship between ethical behavior and religion, gender and culture can be divided into three areas. Firstly, is related to ethical behavior and method of teaching ethics, ethical behavior, and students and the ethical behavior of professionals.

\section{Ethics in Education}

Lam and Shi (2007) believes that there is a flaw in the current education system and needed improvement so that the role of education especially in developing moral values could be reestablished. Therefore, they believe that it is wrong to conclude that education does indeed play no role in moral development. His view on ethical education was also supported by Aldughaither (2012), who believes that teaching of ethics to students is important especially since the early years of their study. This is because the problems and dilemmas were faced by students as early as the first year. Therefore, he suggested studying the methods of instruction and contents of the subject to investigate the perspective of students on ethical subjects. Others, such as Lowry (2003) try to explain whether the method of teaching and the timing of such courses is important. This is because, in the United Kingdom, ethics courses are taught at postgraduate and final year undergraduate degree students.

As Nichols and Zimmer (1985) put it, the subject of ethics evolved like the history of mankind from savagery to civilize society. However, he believes that colleges are still struggling with the best way to teach ethics as a subject. "The powerful in government, commerce and religion spoke out loudly through their actions or lack of action. Ethical standards are living the values. They represent a vital and critical guiding force in the functioning of our society" (Nichols and Zimmer, 1985: 1786). Ruegger and King (1992) believe that more and more cases of unethical 
behavior among corporations and officers show that they are juggling between business and their social responsibility. Therefore, the public's concern over business ethics continues, schools of business will be expected to do a better job of teaching ethics in their undergraduate and graduate courses.

\section{Ethical Behavior and Students and Professionals}

At the academic institutional level, Zapiatis and Kambia-Kapardis (2007) while explaining tertiary student's ethical judgment in Cyprus academic environment finds that private university students are more tolerant in facing ethical issues related to technology and social media such as sharing their work for individual assignments, copying files, music, and apps from the internet and duplicating copyright e-books rather than ethical issues relevant with selfishness such as not paying much cooperation with group assignments, using bribe and obtaining preferential treatment with instructors and hiding books in the library. Business and non-business students do not differ significantly on any of the ethical factors and students with high-Grade Point Average were less tolerant of issues relevant to selfishness.

Mc Lachlan (2015), Rettinger and Jordan (2005), Burks and Sellani (2008), Murdock (2005), Rawwas et. al (2006), Furman et al (2004), Kennedy and Lawton (1998) and Conroy and Emerson (2004) look for the answer by connecting ethical behavior with religion, besides age and education (Lam and Shi, 2007). To Rawwas, the answer to the relation between religion and ethics could help in assisting teachers in developing curriculum, assigning teaching materials, grading projects, proctoring exams and understanding the mindset of students, and will generally assist businesses in understanding the effect of religion on their employees, managers, and customers. To Kennedy and Lawton, religion controls beliefs and behaviors by serving important purposes for societies and individuals. "Religion promotes social solidarity, partly by providing norms that reduce conflict and also by imposing sanctions against antisocial conduct" (Kennedy and Lawton 1998: 163). Others, such as Lau et al (2005) look at the attitude of workers and employees and look at how far their religiosity and spirituality affected their work. Besides religion, other researchers, such as Lam and Shi (2007) also relate sociodemographic factors such as gender into the equation, by relating how far the sociodemographic factors affect ethical behavior.

\section{Data and Methodology}

At the moment, research regarding the ethical behavior and awareness among students in Sabah and cultural comparison between this area and in other areas in Peninsular Malaysia to form a cultural comparison has not been done.

Firstly, the researcher conducted a literature review to establish a lack of research in the area especially in Sabah (East Malaysia). A quantitative questionnaire was developed consisting of 50 questions that were drafted for students to fill in. The question was drafted based on the Sociology of Knowledge (SoK) theory, the study of the relationship between human thought and the social context within which it arises, and of the effects prevailing ideas have on societies. The theory deals with broad fundamental questions about the extent and limits of social influences on individuals' lives and the social-cultural basics of our knowledge about the world. Among the thinker who used the SoK are Karl Mannheim, Peter Berger, and Syed Hussein Alatas. Out of the 50 questions, the researcher divided 32 questions into six sections using a Likert type scale to determine student's ethical behavior based on the students' social surroundings; ethics in school, religion, home, university education, social and academic. 
The research populations are first-year students who had finished attending a general philosophy class (Introduction to Philosophy) which also includes basic information on ethics, ethical behavior, and important issues. The questionnaire was also pilot tested for reliability where some of the questionnaires were revised, mistakes corrected, and negative statements were corrected to be analyzed using the Statistical Package for Social Sciences (SPSS). The researcher had also analyzed the data using descriptive and inferential statistics, reliability analysis (Cronbach's Alpha), exploratory factor analysis, independent sample $t$-test, paired sample $t$-test and one-way Analysis of Variant (ANOVA) with Post Hoc Multiple Comparison Test (Turkey HSD). All the process was done to test the reliability of the data as well as looking at the outcome of data processed for its significant and correlation between the variables.

\section{Results and Discussion}

The questionnaires were group-administered to 440 students at University Malaysia Sabah and 405 questionnaires were completed and returned to the researchers. Of those, six were incomplete, and thus excluded from the study, reducing the number of usable surveys to 399 and the overall response rate to $90.7 \%$. Table I displays the demographic profile of the participants with five different variables: gender, ethnic origin, year of study, the discipline of studies and type of educational institution.

\section{Factor Analysis}

The researcher also conducted an exploratory factor analysis with the use of SPSS's Principal Component Analysis with Varimax rotation (Kaiser Normalization) to reduce a large number of variables to a smaller number of factors. Exploratory factor analysis is primarily used to reveal the factor structure of the data. The appropriateness of the factor model in the research was indicated by both the Kaiser-Mayer-Olkin $(K M O)$ statistic value of 0.921 , which confirmed its high sampling adequacy, and the significance $\left(x^{2}=5,281 ; p=<.000\right)$ of the Barlett's test of sphericity.

Principal component analysis with Varimax rotation factor analysis revealed six factors with an eigenvalue of greater than 1.0. This six-factor solution explained satisfactory $57.42 \%$ of the total variance. It is important to note that factor loadings of less than 0.350 were excluded. All variables included in the factor analysis were tested for reliability with the utilization of Cronbach's Alpha; a reliability model of internal consistency based on average inter-item correlation. Table II exhibits the results of the factor and descriptive analysis of our data. The six retained factors were named by the researcher as religion, social surroundings, home, ethics at university, academic ethics and school education. However, the question "I know at least one person in my community that have ethical problems" and "I always do something that is not against the norms of my social environment" was excluded because of low factor loading (less than 0.350)

Findings revealed that participating students believe that most of their ethical awareness of ethical issues are related to religion, suggesting that most students believe that religious teachings contain a clear ethical and moral code of conduct (mean 4.712) and the lowest toward academic-related ethics (mean 2.88). Students seem to believe that religion also helps them in making a good decision (mean 4.564), helps them in controlling their daily attitude while they believe that religion also plays an important role in providing the right code of conduct (mean 4.303).

The findings are following Rawwas et. al. (2006) findings regarding the relation between ethical beliefs and religion. The study, which examines student's ethical beliefs from religious 
and secular universities finds that even though students from Japanese secular universities tended to score higher on achievement and humanism, and lower on theism and positivism than did students of the Japanese religious university. Besides, students of the Japanese secular university were somewhat more sensitive to academic dishonesty practices than were students of the Japanese religious university. Other findings by Lam and Shi (2008) in mainland China also find out that religion played an important role in affecting ethical attitudes, however, its effect varied with different types of religions; Christianity was found to be most favorable to higher ethical standards, but people of traditional Chinese religion had higher acceptability of unethical behaviors involving social concerns compared to people with no religion.

On the other hand, students also believe that ethics related to academics, such as downloading music and apps using public Wi-Fi at the university as not an unethical behavior (mean 2.163), sharing individual assignments with friends (mean 2.298), using the internet as a source of information and not giving credit to sources (mean 3.712).

The second-ranked ethical behavior, according to students is school ethics, where most students believe that the ethical subject and awareness should be taught in high school (mean 4.612). Students who participated also believe that their ethical awareness started when they are in high school (mean 4.053) while they also credit friends and family as their source of ethical issues (mean 4.018).

\section{Independent Sample T-test}

The researcher also investigated whether significant statistical differences exist between the respondents according to their gender, marital status, the course they took, the result, understanding of ethics, smartphone used and known issues in ethics. As shown in Table III, an independent sample t-test revealed that several differences exist between the respondents. It was found that women's awareness of ethical issues related to ethic in school and academic ethics are higher than men. Married students are more aware of ethical behavior related to school and at home compared to men.

The non-business student is more aware of ethical behavior related to academic, religion and home compared to their business counterpart. Moreover, students with a better result with a high-Grade Point Average (between 3.01 and 4.00) are more aware of ethical behavior related to academics and religion compared to students who compared to those with average or below academic performances (below 3.0) in the previous semester. However, students who are below academic performance are more aware of ethical behavior in religion and their home. They also have a slightly higher awareness of ethical behavior in their social life. This shows that students who get average results are more socially aware of what happens at home and social life compared to students who get better results than them.

Furthermore, students who admit that they understand the meaning of ethics and had known ethical issues while at school are more aware of ethical behavior in the five out of the six factors analyzed, religion, academic, school, home and in the university compared to students who admit that they do not understand the meaning of ethics and do not know any ethical issues while at the school level. Finally, students who have smartphones are more aware of ethical behavior in their social, home, university and religion compared to students who do not own a smartphone. However, the small number of students who do not own a smartphone are more aware of ethical behavior in the academic field at the university and ethical behavior in school. 


\section{One-way ANOVA}

One-way ANOVA test was used to identify statistical differences between respondents and their age, previous qualification, race, original residence and area of residence. Out of the variables tested using ANOVA, only three variables show significant value: their race, original residence, and area of residence. As shown in Table IV a that shows differences between the respondent and their race, differences exist in three of the six ethical factors: university ethics, academic ethics, and ethics in school. Once the existing differences among the means of the five groups were revealed, Post Hoc Multiple Comparison tests were utilized to determine which means differ. The Tukey Honestly Significant Difference test (HSD) (Table IV b) was used since it is a very conservative pairwise comparison test that minimizes the possibility for Type I errors. To sum it up Table IV c shows the relation between students' race and their awareness of ethical issues in different scenarios. In particular, the Chinese are less aware of ethical issues while in school compared to other races. Furthermore, the Chinese are also less aware of ethical behavior related to religion compared to other races. International students are less aware of ethical behavior at the university, in the academic world and school. This is clearly shown in the lowest mean score of the international student compared to their local counterpart. Furthermore, students living in other areas than cities and outskirts tend to be less aware of ethical behavior concerning their religion compared to those living in cities and outskirts areas.

\section{Concluding Comments}

This present study was undertaken to investigate university students' ethical awareness on ethical issues related to their home surroundings, religion, academic behavior at the university, in school and their social life. This is done at the University Malaysia Sabah, Labuan International campus where students from the different cultural and religious background is populated in the hope to improve the social awareness. Findings revealed the following: (a) Most students agree that religion serves the basis of their ethical behavior. (b) Most students believe that using the internet to download apps, music, etc. It is not considered as unethical. (c) Female respondents' awareness of ethical issues related to ethics in school and academic ethics is higher than the male respondent. (d) Married students are more aware of ethical behavior related to school and at home compared to men. (e) The non-business student is more aware of ethical behavior related to academic, religious and home compared to their business counterpart. (f) Moreover, students with a better result with a high-Grade Point Average (between 3.01 and 4.00) are more aware of ethical behavior related to academics and religion compared to those with average or below academic performances (below 3.0) in the previous semester. However, students who are below academic performance are more aware of ethical behavior in religion and their home. They also have a slightly higher awareness of ethical behavior in their social life.

Comparing the findings with similar studies conducted locally and abroad, we can identify both similarities and differences. The findings made here are aligned with (e.g. Lam et. al, 2008) in regard to the student's ethical behavior and religion. It seems that in the $21^{\text {st }}$-century religion still plays an important role in a person's ethical behavior. Compared to those with no religion at all, people with religion seem to be more concerned with unethical behavior compared to people with no religion at all. The research is also aligned with the study made by Rettinger and Jordan (2003) and Rawwas et al. (2006). Other findings, which are aligned with other researchers (Ramayah et al. 2009) is that the student's behavior is also very closely related to internet piracy and sharing of applications over the internet. The study also revealed that effect and intention are significant mediators of Internet piracy behavior among students and should be controlled by universities. Furthermore, the result of this study also aligns with Aliyu et al 
(2010), Furthermore, the findings aligned with Aliyu (2010), Durwood and King (1995), Borkowski and Ugras (1998), Ritter (2006), Ameen et al. (1996) and Ahmad and Seet (2009) relating to gender where Aliyu finds that male students reported the highest level of computer security and ethics violations than their female counterparts.

But unlike the findings made by Burkowski and Ugras (1998) which found the relationship between an undergraduate major in the ethical attitudes and behavior of business students a 'difficult to interpret' the study found out that there is a significant relation between courses undertook by the student and their ethical awareness. Non-business students are more aware of ethical behavior compared to business students. With regards to student's results (CGPA), the findings of this study align with similar studies by Zopiatis and Krambia-Kapardis (2007). Students with high-Grade Point Average are more aware of unethical behavior compared to students with low-Grade Point Average.

Reflecting on the research findings, it is recommended that several actions will be taken by the relevant authority to instill awareness among students concerning ethical behavior, especially in the academic field. There should be an awareness campaign, which focused on all students, especially first-year students to develop awareness and reflect what they have learned in school on the values of being a university student that needs to be maintained. This is because some students were influenced by their peers into behaving unethically while at the university. Furthermore, students are also coerced into behaving unethically due to ill preparation, especially during final examinations. Light punishments, if they are caught, is also one of the factors that led student into doing academic dishonesty. According to Zopiatis and KrambiaKapardis (2007), education institutions should develop and implement a students' honor code, clarifying the ethical behavior and attitudes within the academic environment. Such guidelines should emphasize value such as academic integrity, honesty, trust, and fairness; all of which are essential to the individual's personal and professional development (p. 660).

\section{References}

Ahmad, Noor Hazlina; Seet, Pi-Shen, 2010, Gender Variations in Ethical and Socially Responsible Considerations among SME Entrepreneurs in Malaysia in International Journal of Business and Society, Vol. 11, No. 1.

Aldughaither, Saud K., 2012, Student perspectives on a course on medical ethics in Saudi Arabia in Journal of Taibah University Medical Sciences 7(2), 113-117.

Aliyu, M., Abdallah, N.A.O., Lasisi, N.A. and Diyar, D, 2010, Information and Communication Technology for the Muslim World (ICT4M), proceeding of the 2010 International Conference on Jakarta 13-14 Dec. 2010

Ameen, Elsie C., Guffey, Daryl M., McMillan, Jeffrey J., 1996, Gender differences in determining the ethical sensitivity of future accounting professionals in Journal of Business Ethics, Volume 15, Issue 5, pp 591-597

Barbara A. Ritter, 2006, Can Business Ethics be Trained? A Study of the Ethical Decisionmaking Process in Business Students in Journal of Business Ethics, Volume 68, Issue 2, pp 153-164

Borkowski, Susan C. and Ugras, Yusuf J., 1998, Business Students and Ethics: A MetaAnalysis in Journal of Business Ethics 17: 1117-1127.

Burks, Bryan D., Sellani, Robert J., 2008, Ethics, Religiosity, and Moral Development of Business Students in Journal of Leadership, Accountability and Ethics. 49-71.

Conroy, Stephen J. and Emerson, Tisha L.N., 2004, Business Ethics and Religion: Religiosity as a Predictor of Ethical Awareness Among Students, in Journal of Business Ethics, Volume 50, Issue 4, pp 383-396 
Conroy, Stephen J. and Emerson, Tisha L.N., 2004. Business Ethics and Religion: Religiosity as a Predictor of Ethical Awareness Among Students, in Journal of Business Ethics, Volume 50, Issue 4, pp 383-396.

Furman, Leola Dyrud, Benson, Perry W., Grimwood, Cordelia and Canda, Edward, 2004, Religion and Spirituality in Social Work Education and Direct Practice at the Millenium: A Survey of UK Social Worker, in British Journal of Social Work, 34, pp. 767-792.

Kennedy, Ellen J. and Lawton, Leigh, 1998, Religiousness and Business Ethics, in Journal of Business Ethics 17: 163-175.

Lam, Kit Chun, Shi, Guicheng, 2008, Factors Affecting Ethical Attitudes in Mainland China and Hong Kong, in Journal of Business Ethics, Volume 77, Issue 4, pp 463-479

Lau, Linda K., Haug, James C. and Wright, Linda B., 2012, College Faculty and Administrators' Perception of Student Ethics in Journal of Business Diversity vol. 12(1), 107-121

MacKinnon, Barbara, 2001. Ethics: Theory and Contemporary Issues, United States: Wadsworth/Thomson Learning.

Mc Lachlan, H.V., 2008, The Religious Beliefs Of Students And The Teaching Of Medical Ethics: A Comment On Brassington in Journal of Medical Ethics, Vol34:396-398

McNichols and Zimmerer, 1985, Situational Ethics: An empirical Study of Differentiators of Student Attitudes, Journal of Business Ethics, 4, 175-180.

McNichols and Zimmerer, 1985, Situational Ethics: An empirical Study of Differentiators of Student Attitudes, Journal of Business Ethics, 4, 175-180.

Murdock, Vicki, 2005, Guided by Ethics, Journal of Gerontological Social Work, 45:1-2, 131154

Prior, Mary, Rogerson, Simon, Fairweather, Ben, 2002, The Ethical Attitudes Of Information Systems Professionals: Outcomes Of An Initial Survey in Telematics and Informatics, 19 21-36

Rawwas, Mohammed Y. A., Swaidan, Ziad and Al-Khatib, Jamal, 2006, Does Religion Matter? A Comparison Study of the Ethical Beliefs of Marketing Students of Religious and Secular Universities in Japan, Journal of Business Ethics, 65: 69-86

Rettinger, David A. and Jordan, Augustus E., 2005, The Relations Among Religion, Motivation, and College Cheating: A Natural Experiment in Ethics \& Behavior, 15:2, 107-129

Ruegger, D and King, EW, 1992, A Study Of The Effect Of Age And Gender Upon Student Business Ethics in Journal of Business Ethics,

Saud K. Aldughaither, 2012, Student perspectives on a course on medical ethics in Saudi Arabia in Journal of Taibah University Medical Sciences, 7(2), 113-117.

Zopiatis, Anastasios A. and Krambia-Kapardis, Maria, 2008, Ethical Behaviour of Tertiary Education Studentin Cyprus in Journal of Business Ethics, Vol 81, pp. 647-663. 


\section{APPENDIX}

Table I: Demographic Profile Of Respondents

\begin{tabular}{|c|c|c|c|c|c|}
\hline & & Frequency & Percent & $\begin{array}{c}\text { Valid } \\
\text { Percent } \\
\end{array}$ & $\begin{array}{c}\text { Cumulative } \\
\text { Percent }\end{array}$ \\
\hline \multirow[t]{3}{*}{ Gender } & Male & 96 & 24.1 & 24.1 & 24.1 \\
\hline & Female & 303 & 75.9 & 75.9 & 100.0 \\
\hline & Total & 399 & 100.0 & 100.0 & 100 \\
\hline \multirow[t]{4}{*}{ Age } & Below 19 & 18 & 4.5 & 4.5 & 4.5 \\
\hline & $20-24$ & 377 & 94.5 & 94.5 & 99.0 \\
\hline & $\begin{array}{ll}25 & \text { and } \\
\text { above }\end{array}$ & 4 & 1.0 & 1.0 & 100.0 \\
\hline & Total & 399 & 100.0 & 100.0 & \\
\hline \multirow[t]{3}{*}{ Course } & FKAL & 385 & 96.5 & 96.5 & 96.5 \\
\hline & FKI & 14 & 3.5 & 3.5 & 100.0 \\
\hline & Total & 399 & 100.0 & 100.0 & \\
\hline \multirow[t]{6}{*}{ Race } & Malay & 186 & 46.6 & 46.6 & 46.6 \\
\hline & Chinese & 69 & 17.3 & 17.3 & 63.9 \\
\hline & Indian & 19 & 4.8 & 4.8 & 68.7 \\
\hline & Sabahan & 112 & 28.1 & 28.1 & 96.7 \\
\hline & Sarawakian & 13 & 3.3 & 3.3 & 100.0 \\
\hline & Total & 399 & 100.0 & 100.0 & \\
\hline \multirow[t]{5}{*}{ Origin } & $\begin{array}{l}\text { Peninsula } \\
\text { Malaysia }\end{array}$ & 218 & 54.6 & 54.6 & 54.6 \\
\hline & Sabah & 150 & 37.6 & 37.6 & 92.2 \\
\hline & Sarawak & 28 & 7.0 & 7.0 & 99.2 \\
\hline & $\begin{array}{l}\text { International } \\
\text { Student }\end{array}$ & 3 & .8 & .8 & 100.0 \\
\hline & Total & 399 & 100.0 & 100.0 & \\
\hline \multirow[t]{4}{*}{ Region } & City & 218 & 54.6 & 54.6 & 54.6 \\
\hline & Outskirts & 179 & 44.9 & 44.9 & 99.5 \\
\hline & Other & 2 & .5 & .5 & 100.0 \\
\hline & Total & 399 & 100.0 & 100.0 & \\
\hline \multirow[t]{5}{*}{ Religion } & Islam & 282 & 70.7 & 70.7 & 70.7 \\
\hline & Christianity & 46 & 11.5 & 11.5 & 82.2 \\
\hline & Hindu & 15 & 3.8 & 3.8 & 86.0 \\
\hline & buddha & 56 & 14.0 & 14.0 & 100.0 \\
\hline & Total & 399 & 100.0 & 100.0 & \\
\hline \multirow{5}{*}{$\begin{array}{l}\text { Religious } \\
\text { Beliefs }\end{array}$} & None & 2 & .5 & .5 & .5 \\
\hline & Religious & 180 & 45.1 & 45.1 & 45.6 \\
\hline & Moderate & 210 & 52.6 & 52.6 & 98.2 \\
\hline & $\begin{array}{l}\text { Less } \\
\text { Religious }\end{array}$ & 7 & 1.8 & 1.8 & 100.0 \\
\hline & Total & 399 & 100.0 & 100.0 & \\
\hline
\end{tabular}


TABLE II

Factor and Descriptive Analysis

\begin{tabular}{|c|c|c|c|c|c|c|c|c|}
\hline \multirow[b]{2}{*}{ Factor Items } & \multicolumn{4}{|c|}{ Factor Analysis } & \multicolumn{4}{|c|}{ Descriptive Analysis } \\
\hline & $\begin{array}{l}\text { Loadin } \\
\text { g }\end{array}$ & $\begin{array}{l}\text { Eigen } \\
\text { Values }\end{array}$ & $\begin{array}{l}\text { Percentage } \\
\text { of explained } \\
\text { variance }\end{array}$ & $\begin{array}{l}\text { Reliability } \\
\text { alpha } \\
\text { (Cronbach) }\end{array}$ & Mean & $\begin{array}{l}\text { Standard } \\
\text { Deviation }\end{array}$ & $\begin{array}{l}\text { Overall } \\
\text { rank }\end{array}$ & Comments \\
\hline Factor 1: Religion (5 items) & & 2.855 & 9.21 & 0.877 & 4.470 & 0.176 & 1 & \\
\hline Do religious teachings control my daily attitude? & .661 & & & & 4.491 & 0.776 & & \\
\hline Religious teachings contain a clear ethical and moral code of conduct. & .714 & & & & 4.712 & 0.626 & & \\
\hline Religious teaching helps me in making a good and sound decision. & .710 & & & & 4.564 & 0.730 & & \\
\hline I understand clearly the ethical code of conduct in my religion. & .745 & & & & 4.303 & 0.744 & & \\
\hline $\begin{array}{l}\text { My understandings of religious knowledge come from friends and family } \\
\text { members. }\end{array}$ & .634 & & & & 4.298 & 0.772 & & \\
\hline Factor 2: School Education & & 9.006 & 29.052 & 0.774 & 4.053 & 0.362 & 2 & \\
\hline I already known about ethical issues since $i$ was in school.] & .602 & & & & 4.103 & 0.738 & & \\
\hline I already read about the ethical subjects since i was in school.] & .598 & & & & 3.917 & 0.780 & & \\
\hline The ethical subject and awareness should be taught in schools.] & .563 & & & & 4.612 & 0.670 & & \\
\hline My understanding of ethical issues at school is comprehensive and enough. & .536 & & & & 3.617 & 0.866 & & \\
\hline My understanding of ethical issues is obtained from friends and family.] & .622 & & & & 4.018 & 0.768 & & \\
\hline Factor 3: Home & & 1.78 & 5.741 & 0.773 & 3.866 & 0.355 & 4 & \\
\hline The people around the place i live are aware of ethical issues. ] & .604 & & & & 3.434 & 0.913 & & \\
\hline My family members always advise me to follow the rule of ethics.] & .730 & & & & 4.436 & 0.716 & & \\
\hline My friends at home are aware of ethical issues. ] & .653 & & & & 3.627 & 0.853 & & \\
\hline $\begin{array}{l}\text { Ethical issues are among the important issues discussed by the people in my } \\
\text { community.] }\end{array}$ & .623 & & & & 3.920 & 0.896 & & \\
\hline Most of my understanding of ethical issues are influenced by friends and family.] & .608 & & & & 4.055 & 0.849 & & \\
\hline Factor 4: Ethics as University Subject & & 1.616 & 5.213 & 0.733 & 3.870 & 0.365 & 3 & \\
\hline Other than this subject, I had already taken other ethical subjects.] & .411 & & & & 3.363 & 1.047 & & \\
\hline The method of teachings of ethical subjects are clear and sufficient. ] & .671 & & & & 3.925 & 0.766 & & \\
\hline My friends and family also think that ethical subjects are important.] & .734 & & & & 4.231 & 0.728 & & \\
\hline The mainframe of ethical subjects is compatible with the course that $i$ took.] & .613 & & & & 3.960 & 0.769 & & \\
\hline Factor 5: Social Environment & & 1.295 & 4.177 & 0.768 & 3.655 & 0.195 & 5 & \\
\hline Social environment mostly influences my daily life.] & .757 & & & & 3.952 & 0.930 & & \\
\hline Most decision that I made is influenced by my social environment] & .759 & & & & 3.471 & 1.017 & & \\
\hline Sometimes i did something I dislike for the sake of social environment.] & .660 & & & & 3.491 & 1.070 & & \\
\hline The influence of social environment plays an important role in my life.] & .841 & & & & 3.647 & 1.048 & & \\
\hline Factor 6: Academic Ethics & & 1.193 & 3.847 & 0.667 & 3.178 & 0.926 & 6 & \\
\hline I know that I should not share my individual assignment with friends. & .463 & & & & 2.298 & 1.254 & & \\
\hline I give full attention to my group assignment.] & .674 & & & & 4.263 & 0.904 & & \\
\hline
\end{tabular}

Copyright $\odot$ GLOBAL ACADEMIC EXCELLENCE (M) SDN BHD - All rights reserved 


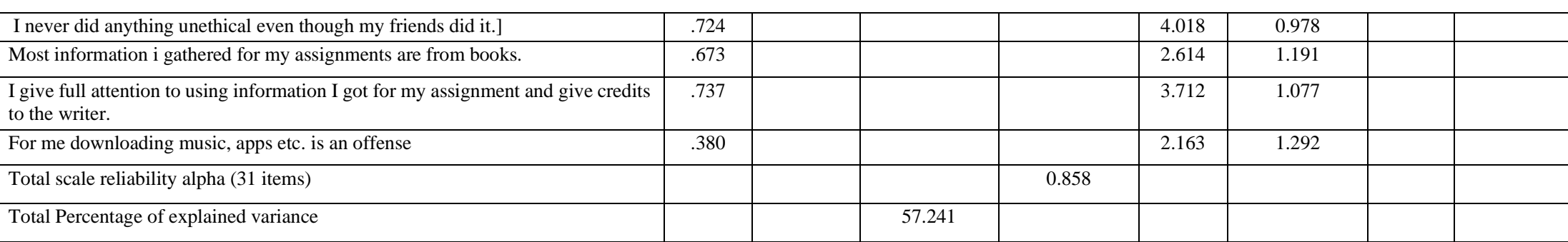

KMO measure of sampling adequacy $=0.901$. Extraction Method: Principal Component Analysis. The question "I known at least one person in my community that

have ethical problems" and "I always do something that is not against the norms of my social environment" was excluded because of low factor loading (less than 0.350)

Scale: 1- Strongly Disagree; 2-Disagree; 3- Neither Agree nor Disagree; 4- Agree; 5- Strongly Agree 
Table III:

Difference According To Gender, Marriage Status, Course, Result, Understanding Of Ethics, Smartphone And Known Issues In Ethics Independent Sample t-test

\begin{tabular}{|c|c|c|c|c|c|c|}
\hline Ethical Factor & Group & $\mathbf{N}$ & Mean & $\begin{array}{c}\text { Std } \\
\text { Deviation }\end{array}$ & $\mathbf{t}$ & $\begin{array}{l}\text { Sig. (2 } \\
\text { tailed) }\end{array}$ \\
\hline \multirow[t]{2}{*}{ ACADEMICNEW } & Male & 96 & 17.7917 & 5.04697 & -3.013 & 0.003 \\
\hline & Female & 303 & 19.4719 & 3.72281 & & \\
\hline \multirow[t]{2}{*}{ SCHOOLETHICS } & Male & 96 & 19.8438 & 2.9994 & -1.711 & 0.088 \\
\hline & Female & 303 & 20.3993 & 2.69822 & & \\
\hline \multirow[t]{2}{*}{ RELIGIONNEW } & Male & 96 & 22.0938 & 3.87455 & -0.853 & 0.395 \\
\hline & Female & 303 & 22.4554 & 2.6602 & & \\
\hline \multirow[t]{2}{*}{ ENVIRONMENTNEW } & Male & 96 & 23.1458 & 4.27226 & -0.156 & 0.876 \\
\hline & Female & 303 & 23.2112 & 3.31886 & & \\
\hline \multirow[t]{2}{*}{ UNIVERSITYNEW } & Male & 96 & 15.2708 & 3.059 & -0.808 & 0.421 \\
\hline & Female & 303 & 15.5446 & 2.29103 & & \\
\hline \multirow[t]{2}{*}{ SOCIALNEW } & Male & 96 & 18.9375 & 3.87655 & 2.094 & 0.037 \\
\hline & Female & 303 & 18.066 & 3.44622 & & \\
\hline \multirow[t]{2}{*}{ ACADEMICNEW } & Single & 396 & 19.0505 & 4.14026 & -0.952 & 0.342 \\
\hline & Married & 3 & 21.3333 & 3.51188 & & \\
\hline \multirow{2}{*}{ SCHOOLETHICS } & Single & 396 & 20.2626 & 2.78908 & -0.25 & 0.802 \\
\hline & Married & 3 & 20.6667 & 1.1547 & & \\
\hline \multirow[t]{2}{*}{ RELIGIONNEW } & Single & 396 & 22.3687 & 3.00302 & 0.02 & 0.984 \\
\hline & Married & 3 & 22.3333 & 2.3094 & & \\
\hline \multirow[t]{2}{*}{ ENVIRONMENTNEW } & Single & 396 & 23.1894 & 3.57799 & -0.392 & 0.695 \\
\hline & Married & 3 & 24 & 1 & & \\
\hline \multirow[t]{2}{*}{ UNIVERSITYNEW } & Single & 396 & 15.4798 & 2.50409 & 0.101 & 0.92 \\
\hline & Married & 3 & 15.3333 & 1.1547 & & \\
\hline \multirow{2}{*}{ SOCIALNEW } & Single & 396 & 18.2753 & 3.5724 & -0.028 & 0.978 \\
\hline & Married & 3 & 18.3333 & 3.78594 & & \\
\hline \multirow[t]{2}{*}{ ACADEMICNEW } & Finance & 385 & 19.0286 & 4.18227 & -1.621 & 0.125 \\
\hline & COMPUTER & 14 & 20.1429 & 2.445 & & \\
\hline \multirow[t]{2}{*}{ SCHOOLETHICS } & FINANCE & 385 & 20.2701 & 2.80898 & 0.168 & 0.867 \\
\hline & COMPUTER & 14 & 20.1429 & 1.87523 & & \\
\hline \multirow[t]{2}{*}{ RELIGIONNEW } & FINANCE & 385 & 22.3351 & 3.02583 & -1.167 & 0.244 \\
\hline & COMPUTER & 14 & 23.2857 & 1.85757 & & \\
\hline \multirow{2}{*}{ ENVIRONMENTNEW } & FINANCE & 385 & 23.161 & 3.58382 & -1.012 & 0.312 \\
\hline & COMPUTER & 14 & 24.1429 & 2.98347 & & \\
\hline \multirow[t]{2}{*}{ UNIVERSITYNEW } & FINANCE & 385 & 15.4701 & 2.49265 & -0.359 & 0.72 \\
\hline & COMPUTER & 14 & 15.7143 & 2.67261 & & \\
\hline \multirow[t]{2}{*}{ SOCIAL } & FINANCE & 385 & 18.3299 & 3.55943 & 1.593 & 0.112 \\
\hline & COMPUTER & 14 & 16.7857 & 3.64119 & & \\
\hline \multirow[t]{2}{*}{ ACADEMIC } & 3.00 to 4.00 & 226 & 19.5841 & 4.0425 & 2.864 & 0.004 \\
\hline & Below 3.00 & 173 & 18.3931 & 4.17305 & & \\
\hline \multirow[t]{2}{*}{ SCHOOLETHICS } & 3.00 to 4.00 & 226 & 20.115 & 2.82765 & -1.245 & 0.214 \\
\hline & Below 3.00 & 173 & 20.4624 & 2.71195 & & \\
\hline RELIGION & 3.00 to 4.00 & 226 & 21.9336 & 3.13971 & -3.356 & 0.001 \\
\hline
\end{tabular}

Copyright $\odot$ G GLOBAL ACADEMIC EXCELLENCE (M) SDN BHD - All rights reserved 
HOME

UNIVERSITY

SOCIAL

ACADEMIC

SCHOOLETHICS

RELIGION

HOME

UNIVERSITY

SOCIAL

ACADEMIC

SCHOOLETHICS

RELIGION

HOME

UNIVERSITY

SOCIAL

ACADEMIC

SCHOOLETHICS

Below 3.00

173

\begin{tabular}{|l|l|}
\hline 22.9364 & 2.7026 \\
\hline
\end{tabular}

3.00 to 4.00

226

\begin{tabular}{l|l}
22.9115 & 3.58034 \\
\hline
\end{tabular}

Below 3.00

\begin{tabular}{l|l}
173 & 23.5665 \\
\hline
\end{tabular}

3.00 to 4.00

226

15.1903

Below 3.00

173

15.8555

3.00 to 4.00

226

18.0664

3.52275

Below 3.00

18.5491

\begin{tabular}{|l|r} 
Understand Ethics & 368 \\
\hline
\end{tabular}

\begin{tabular}{|l|c|c|c|}
\hline Don't Understand Ethics & 31 & 17.7742 & 4.70255 \\
\hline
\end{tabular}

\begin{tabular}{|l|c|c|c|}
\hline Understand Ethics & 368 & 20.4592 & 2.6858 \\
\hline
\end{tabular}

Don't Understand Ethics

Understand Ethics

Don't Understand Ethics

Understand Ethics

Don't Understand Ethics

Understand Ethics

Don't Understand Ethics

Understand Ethics

Don't Understand Ethics

Have Smartphone

No Smartphone

Have Smartphone

No Smartphone

Have Smartphone

No Smartphone

Have Smartphone

No Smartphone

Have Smartphone

31

368

17.9677

2.89233

\begin{tabular}{l|l}
17.9511 & 2.90312 \\
\hline 2.4511 & 3.86158
\end{tabular}

\begin{tabular}{l|l|l}
31 & 21.3871 & 3.86158 \\
\hline
\end{tabular}

\begin{tabular}{l|l} 
& \\
\hline-1.824 & 0.069 \\
\hline
\end{tabular}

DOI: $10.35631 / I R J S M I .24008$

ACADEMIC

SCHOOLETHCS

RELIGION

HOME

UNIVERSITY

\begin{tabular}{|l|c|c|c|c|c|}
\hline No Smartphone & 3 & 19.3333 & 11.71893 & 0.575 & 0.623 \\
\hline Have Smartphone & 396 & 15.5076 & 2.43549 & & \\
\hline No Smartphone & 3 & 11.6667 & 6.80686 & 0.977 & 0.431 \\
\hline Have Smartphone & 396 & 18.3182 & 3.51269 & 2.755 & 0.006 \\
\hline No Smartphone & 384 & 19.0755 & 4.13317 & 1.367 & 0.196 \\
\hline $\begin{array}{l}\text { Know Ethical Issues at } \\
\text { School }\end{array}$ & 12 & 17.75 & 3.27872 & & \\
\hline $\begin{array}{l}\text { Don't Know Ethical Issues at } \\
\text { School }\end{array}$ & 384 & 20.3281 & 2.75485 & 2.471 & 0.014 \\
\hline $\begin{array}{l}\text { Know Ethical Issues at } \\
\text { School }\end{array}$ & 12 & 18.3333 & 2.70801 & & \\
\hline $\begin{array}{l}\text { Don't Know Ethical Issues at } \\
\text { School }\end{array}$ & 384 & 22.4766 & 2.83202 & 2.56 & 0.011 \\
\hline $\begin{array}{l}\text { Know Ethical Issues at } \\
\text { School }\end{array}$ & 12 & 20.3333 & 3.57601 & & \\
\hline $\begin{array}{l}\text { Don't Know Ethical Issues at } \\
\text { School }\end{array}$ & 384 & 23.2839 & 3.46412 & 1.101 & 0.272 \\
\hline $\begin{array}{l}\text { Know Ethical Issues at } \\
\text { School }\end{array}$ & 12 & 22.1667 & 3.37998 & & \\
\hline $\begin{array}{l}\text { Don't Know Ethical Issues at } \\
\text { School }\end{array}$ & 12 & 13.8333 & 2.69118 & & \\
\hline $\begin{array}{l}\text { Know Ethical Issues at } \\
\text { School }\end{array}$ & 384 & 15.5677 & 2.41202 & 2.445 & 0.015 \\
\hline $\begin{array}{l}\text { Don't Know Ethical Issues at } \\
\text { School }\end{array}$ & & & & \\
\hline
\end{tabular}

Copyright $\odot$ GLOBAL ACADEMIC EXCELLENCE (M) SDN BHD - All rights reserved 
SOCIAL

\begin{tabular}{|l|c|c|c|c|c|}
\hline $\begin{array}{l}\text { Know Ethical Issues at } \\
\text { School }\end{array}$ & 384 & 18.2734 & 3.50691 & -0.869 & 0.385 \\
\hline $\begin{array}{l}\text { Don't Know Ethical Issues at } \\
\text { School }\end{array}$ & 12 & 19.1667 & 3.51188 & & \\
\hline
\end{tabular}

Note: Equal variances assumed

TABLE IV

(a) Difference According to Student's Race

One-way ANOVA

ANOVA

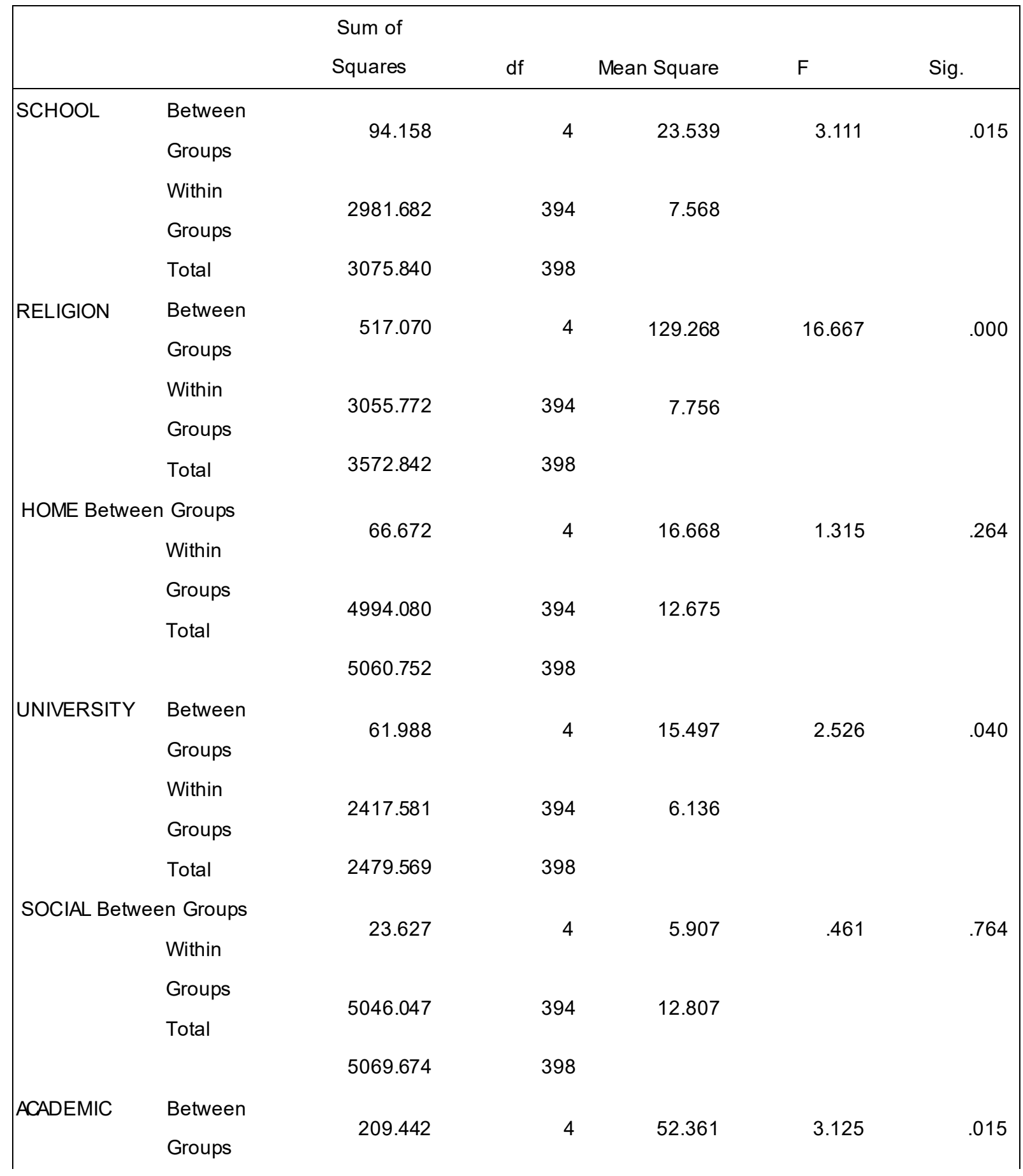




\begin{tabular}{|llll|} 
Within & 6601.731 & 394 & 16.756 \\
Groups & 6811.173 & 398 \\
Total & 698 \\
\hline
\end{tabular}

(b) Post Hoc Multiple Comparison Tests (Tukey HSD)

\section{Multiple Comparisons}

\begin{tabular}{|c|c|c|c|c|c|}
\hline \multicolumn{3}{|l|}{ Dependent Variable } & $\begin{array}{c}\text { Mean } \\
\text { Difference } \\
(\mathrm{I}-\mathrm{J})\end{array}$ & $\begin{array}{c}\text { Std. } \\
\text { Error }\end{array}$ & Sig. \\
\hline \multirow[t]{20}{*}{ SCHOOL ETHICS } & \multirow[t]{4}{*}{ Malay } & Chinese & .72020 & .38777 & .342 \\
\hline & & Indian & -.75806 & .66256 & .783 \\
\hline & & Sabahan & -.18664 & .32902 & .980 \\
\hline & & Sarawakian & -1.83499 & .78919 & .139 \\
\hline & \multirow[t]{4}{*}{ Chinese } & Malay & -.72020 & .38777 & .342 \\
\hline & & Indian & -1.47826 & .71273 & .233 \\
\hline & & Sabahan & -.90683 & .42101 & .200 \\
\hline & & Sarawakian & $-2.55518^{*}$ & .83175 & .019 \\
\hline & \multirow[t]{4}{*}{ Indian } & Malay & .75806 & .66256 & .783 \\
\hline & & Chinese & 1.47826 & .71273 & .233 \\
\hline & & Sabahan & .57143 & .68255 & .919 \\
\hline & & Sarawakian & -1.07692 & 99017 & .813 \\
\hline & \multirow[t]{4}{*}{ Sabahan } & Malay & .18664 & .32902 & .980 \\
\hline & & Chinese & .90683 & .42101 & .200 \\
\hline & & Indian & -.57143 & .68255 & .919 \\
\hline & & Sarawakian & -1.64835 & .80604 & .247 \\
\hline & \multirow[t]{4}{*}{ Sarawakian } & Malay & 1.83499 & .78919 & .139 \\
\hline & & Chinese & $2.55518^{*}$ & .83175 & .019 \\
\hline & & Indian & 1.07692 & .99017 & .813 \\
\hline & & Sabahan & 1.64835 & .80604 & .247 \\
\hline \multirow[t]{10}{*}{ RELIGION } & \multirow[t]{4}{*}{ Malay } & Chinese & $2.85951^{*}$ & .39256 & .000 \\
\hline & & Indian & -.08404 & .67074 & 1.000 \\
\hline & & Sabahan & -.34015 & .33308 & .846 \\
\hline & & Sarawakian & -.16501 & .79893 & 1.000 \\
\hline & \multirow[t]{4}{*}{ Chinese } & Malay & $-2.85951^{*}$ & .39256 & .000 \\
\hline & & Indian & $-2.94355^{*}$ & .72153 & .001 \\
\hline & & Sabahan & $-3.19966^{*}$ & .42620 & .000 \\
\hline & & Sarawakian & $-3.02453^{*}$ & .84202 & .003 \\
\hline & \multirow[t]{2}{*}{ Indian } & Malay & .08404 & .67074 & 1.000 \\
\hline & & Chinese & $2.94355^{*}$ & .72153 & .001 \\
\hline
\end{tabular}




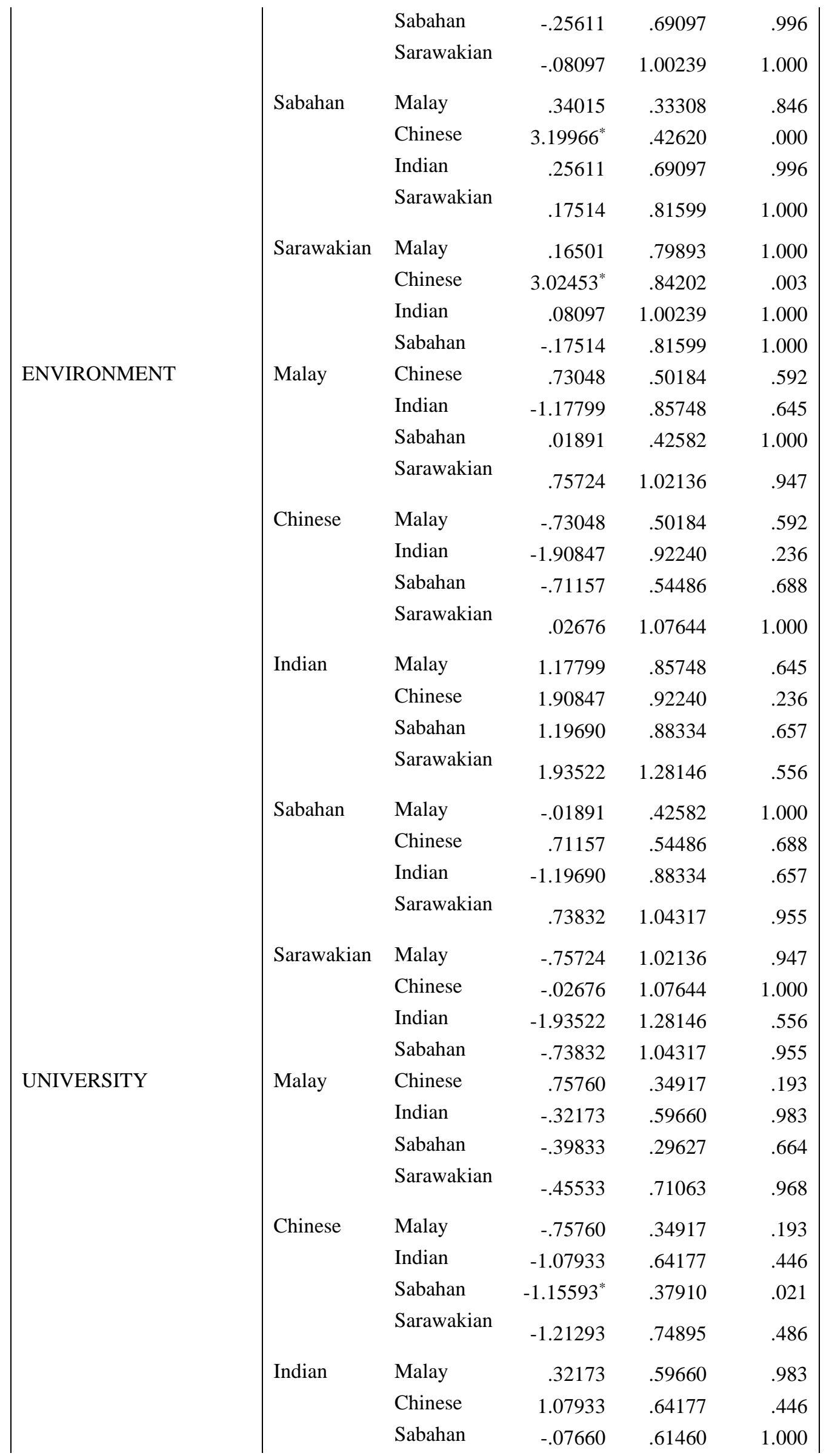


SOCIAL

ACADEMIC

\begin{tabular}{|c|c|c|c|c|}
\hline & Sarawakian & -.13360 & .89160 & 1.000 \\
\hline \multirow[t]{4}{*}{ Sabahan } & Malay & .39833 & .29627 & .664 \\
\hline & Chinese & $1.15593^{*}$ & .37910 & .021 \\
\hline & Indian & .07660 & .61460 & 1.000 \\
\hline & Sarawakian & -.05701 & .72580 & 1.000 \\
\hline \multirow[t]{4}{*}{ Sarawakian } & Malay & .45533 & .71063 & .968 \\
\hline & Chinese & 1.21293 & .74895 & .486 \\
\hline & Indian & .13360 & .89160 & 1.000 \\
\hline & Sabahan & .05701 & .72580 & 1.000 \\
\hline \multirow[t]{4}{*}{ Malay } & Chinese & -.11898 & .50445 & .999 \\
\hline & Indian & -1.04499 & .86193 & .744 \\
\hline & Sabahan & -.33353 & .42803 & .937 \\
\hline & Sarawakian & .03598 & 1.02666 & 1.000 \\
\hline \multirow[t]{4}{*}{ Chinese } & Malay & .11898 & .50445 & .999 \\
\hline & Indian & -.92601 & .92719 & .856 \\
\hline & Sabahan & -.21454 & .54769 & .995 \\
\hline & Sarawakian & .15496 & 1.08203 & 1.000 \\
\hline \multirow[t]{4}{*}{ Indian } & Malay & 1.04499 & .86193 & .744 \\
\hline & Chinese & .92601 & .92719 & .856 \\
\hline & Sabahan & .71147 & .88793 & .930 \\
\hline & Sarawakian & 1.08097 & 1.28811 & 918 \\
\hline \multirow[t]{4}{*}{ Sabahan } & Malay & .33353 & .42803 & .937 \\
\hline & Chinese & .21454 & .54769 & .995 \\
\hline & Indian & -.71147 & .88793 & .930 \\
\hline & Sarawakian & .36951 & 1.04858 & .997 \\
\hline \multirow[t]{4}{*}{ Sarawakian } & Malay & -.03598 & 1.02666 & 1.000 \\
\hline & Chinese & -.15496 & 1.08203 & 1.000 \\
\hline & Indian & -1.08097 & 1.28811 & .918 \\
\hline & Sabahan & -.36951 & 1.04858 & .997 \\
\hline \multirow[t]{4}{*}{ Malay } & Chinese & -.37611 & .57699 & .966 \\
\hline & Indian & $-2.86276^{*}$ & .98588 & .032 \\
\hline & Sabahan & -.56154 & .48958 & .781 \\
\hline & Sarawakian & 1.84574 & 1.17430 & .516 \\
\hline \multirow[t]{4}{*}{ Chinese } & Malay & .37611 & .57699 & .966 \\
\hline & Indian & -2.48665 & 1.06052 & .133 \\
\hline & Sabahan & -.18543 & .62645 & .998 \\
\hline & Sarawakian & 2.22185 & 1.23763 & .378 \\
\hline \multirow[t]{4}{*}{ Indian } & Malay & $2.86276^{*}$ & .98588 & .032 \\
\hline & Chinese & 2.48665 & 1.06052 & .133 \\
\hline & Sabahan & 2.30122 & 1.01562 & .158 \\
\hline & Sarawakian & $4.70850^{*}$ & 1.47335 & .013 \\
\hline
\end{tabular}




\begin{tabular}{|llrrr|} 
Sabahan & Malay & .56154 & .48958 & .781 \\
& Chinese & .18543 & .62645 & .998 \\
& Indian & -2.30122 & 1.01562 & .158 \\
\cline { 2 - 5 } Sarawakian & Sarawakian & 2.40728 & 1.19938 & .264 \\
& Malay & -1.84574 & 1.17430 & .516 \\
& Chinese & -2.22185 & 1.23763 & .378 \\
& Indian & $-4.70850^{*}$ & 1.47335 & .013 \\
& Sabahan & -2.40728 & 1.19938 & .264
\end{tabular}

* The mean difference is significant at the 0.05 level

\section{(a) Summary of Post Hoc Multiple Comparison Test}

* indicates a significant difference between race and ethical awareness in school, university, religion, and academics.

\begin{tabular}{|c|c|c|c|c|c|}
\hline School Et & Malay & Chinese & Indian & Sabahan & Sarawakian \\
\hline \multicolumn{6}{|l|}{ Malay } \\
\hline Chinese & & & & * & \\
\hline \multicolumn{6}{|l|}{ Indian } \\
\hline \multicolumn{6}{|l|}{ Sabahan } \\
\hline Sarawakian & & $*$ & & & \\
\hline Religion & Malay & Chinese & Indian & Sabahan & Sarawakian \\
\hline Malay & & $*$ & & & \\
\hline Chinese & & & $*$ & $*$ & $*$ \\
\hline \multicolumn{6}{|l|}{ Indian } \\
\hline Sabahan & & $*$ & & & \\
\hline Sarawakian & & $*$ & & & \\
\hline University & Malay & Chinese & Indian & Sabahan & Sarawakian \\
\hline \multicolumn{6}{|l|}{ Malay } \\
\hline Chinese & & & & $*$ & \\
\hline \multicolumn{6}{|l|}{ Indian } \\
\hline Sabahan & & $*$ & & & \\
\hline \multicolumn{6}{|l|}{ Sarawakian } \\
\hline Academic & Malay & Chinese & Indian & Sabahan & Sarawakian \\
\hline Malay & & & $*$ & & \\
\hline \multicolumn{6}{|l|}{ Chinese } \\
\hline \multicolumn{6}{|l|}{ Indian } \\
\hline \multicolumn{6}{|l|}{ Sabahan } \\
\hline Sarawakian & & & $*$ & & \\
\hline
\end{tabular}

